\title{
Some psychoanalytical meanings of the skin in Leviticus 13-14
}

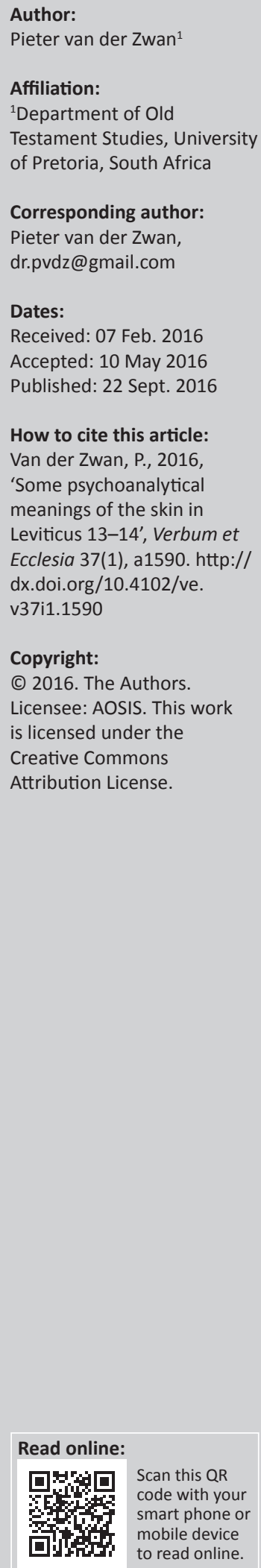

\begin{abstract}
'Psychoanalysing' the different forms of 'scale disease' dealt with in Leviticus 13-14 can shed some light on the way the skin can be interpreted in this context. The eight psychic functions of the skin identified by Anzieu reveal how individuals meet collective anxieties on the surface of the skin where unconscious conflicts about identity boundaries are projected and inscribed.

Intradisciplinary and/or interdisciplinary implications: Traditionally there has been a tension between psychology and religion, due to the Freudian critique of religion. This research intends to show that a deeper understanding of religion leading hopefully to an even deeper religiosity can be achieved by studying bodily features portrayed in a (religious) text from a psychoanalytic perspective.
\end{abstract}

\section{Introduction}

Amongst the approximately 250 body parts mentioned in the Hebrew Bible, the skin has not received the same attention in the reception of this text as others such as the heart, head or hand. The skin is only briefly mentioned and then only for its diseases in the anthropological Old Testament work of Hans Wolff (2002:212-214), and hardly in that of Schroer and Staubli (2005) and in the extensive work of Janowski (2009).

Yet amongst the diseases mentioned in the Hebrew Bible those of the skin occur the most. Skin diseases were likewise viewed differently from other health problems in Mesopotamia where many people with disabilities were incorporated in society, but those with skin diseases were ostracised, even in the netherworld (Walls 2007:15). A text from Emar along the Euphrates River in northern Syria from the second millennium BCE prescribes a certain treatment in the outside gate of someone with scale disease which included dust from the threshold mixed with saliva (Berlejung 2015:32). The symbolism of this therapeutic situation reveals the same meaning attributed to the skin even that long before the biblical texts were composed. From another source, this time from Nuzi, a town southeast of Nineveh, a man is convicted for having claimed another had a contagious skin disease, proving how sensitive the issue was (Steinert 2012:499n.374).

The word, עוֹר [skin], appears 99 times in the Hebrew Bible. That is apart from the hapax legomenon, גִלִדי [my skin], in Job 16:15, which brings the number of times that the skin is explicitly mentioned exactly to 100 . There are many other times when the skin is implied, such as in Deuteronomy 28:27, Numbers 12:10, 19:11-22; Leviticus 19:28; 2 Chronicles 26:16-23 or Song of Songs 1:5-6 but these will not be discussed here (Brown, Driver \& Briggs 1951:736; Lisowsky 1958:1038).

Of these 100 instances, 53 - that is, the majority - occur in Leviticus. These figures therefore suggest a high awareness and sensitivity to the skin in this biblical book. On the other hand, the Psalms which are well known for their high frequency of body references do not mention the skin explicitly even once.

In Leviticus 13 alone 46 instances can be found (but none in chapter 14, although it also deals with צִרַָָת [scale disease]), that is, almost half of all mentions in the Hebrew Bible occur in only one chapter.

Of these 46 instances, 34 , that is, about $75 \%$, refer to some kind of human skin disorder. This is also almost two-thirds of the total of 56 explicit references to the human skin in the Hebrew Bible.

Note: This article forms part of a post-doctoral programme enabled by the National Research Fund for which the author is extremely grateful. It was initially presented as a paper at the International Meeting of the Society of Biblical Literature in Buenos Aires on 21 July 2015, but thereafter extended in Leipzig from 01 August 2015 until 31 January 2016 with the support of an Erasmus Mundus scholarship for which the author is most thankful. 
All of these references to the human skin in Leviticus 13 are therefore about a problematised skin. That not all diseases are regarded as unclean, but only scale diseases, explains the importance of this chapter. As Hartley (1992:200) points out: the diagnoses in this chapter had to be accurate, as the consequences could be so severe. Incidentally, some rabbinic sources claim verse 33 in this chapter to be the exact middle of the Pentateuch (Milgrom 1991:796)!

In the rest of the Pentateuch, except for 3 references to a human being (all about Moses' shining face after his encounter with God [Ex 34:29, 30, 35]), the 2 instances in Genesis, the 17 instances in Exodus and the 8 occurrences in Numbers all refer to the skin of dead animals. In fact, the very first time we find the word, עוֹ [skin], in the Hebrew Bible is in Genesis 3:21 where the hide of an animal is used to cover shame after the 'fall' (almost like a vicarious sacrifice) in the garden of Eden - and by doing so implying death if not killing an animal or even animals. The hides of (dead) animals are always depicted as objects used either for clothing, a tent or as sacrifice.

In Job one finds 11 references, that is more than $10 \%$ of the total in the Hebrew Bible; 10 of these are about Job. Only Job 10:11 and 40:31 celebrate the miracle of the skin; in the former his own and in the latter that of the leviathan. The 3 instances in Lamentations are again about human suffering: being worn out, withered, hot. In Micah both references occur in a context of criminality. The context of Jeremiah 13:23 is again that of punishment, leaving only Ezekiel 37:6 and 8 where a resurrection is hoped for and 2 Kings 1:18 and the 5 instances mentioned above as positively connoted instances. This means that the skin is problematised in more than $90 \%$ of cases and legalised in most of them. In humans the skin is often juxtaposed to bones and flesh, suggesting its essential part in bare human existence.

This highly problematised depiction of an essential body part is perhaps why the skin is not one of the 27 body parts attributed to God and as such implies perhaps that God has no limitations and that the identity of God remains elusive. In the majority of cases the skin seems to suggest liminality as essence of human and animal existence.

In this study the psychoanalytical meanings of the skin in Leviticus 13-14 will be outlined in terms of the work by the French psychoanalyst and one of the main exponents on the psychological meaning of the skin, Didier Anzieu. While working in a dermatological ward he discovered that skin problems always have psychological correlates, if not causes. In addition, current psychological research findings show that skin disorders lead to more stigmatisation, discrimination and humiliation than other visible disorders and are often incorrectly associated with sexual misconduct (Koo \& Yeung 2002:333, 335). Miel (1990:572) briefly mentions the psychological interpretation of biblical 'leprosy' as a psychosomatic disorder. These symbolic evaluations are not only socially important but also psychically crucial.
These psychoanalytic interpretations will finally be situated in the possible context where legislation about scale diseases made sense.

\section{The skin in Leviticus}

The laws in Leviticus about sex, food, circumcision, skin disease(s), childbirth, corpses and genital discharges are all about the body and its boundaries. In chapters 13-14 numerous body parts are explicitly mentioned apart from the skin and the implied eyes: flesh (19 times), hair (18 times), head (13 times), forehead (4 times), beard (3 times), moustache or upper lip (once), feet (once), and the right great toe, right ear and right thumb (each 4 times) as extremities used metonymically to outline the whole body, resonating with the scale disease מֵראשוֹ וְעַד-רַגְלָליו [from his head even to his feet] in Leviticus 13:12 and echoed in the reverse direction by Deuteronomy 28:35 and Job 2:7. The skin is therefore dealt with in a context where the whole body features in the consciousness of the author or authors.

From the overview of the occurrences of the word, עוֹר in the

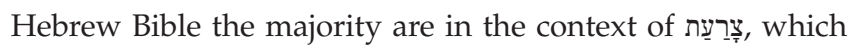
has not only been proven by dermatologists in the 1950s to be a false attribution of the contagious Hansen's disease, but even impossible to identify with any modern pathological category. In this study it will be translated by 'scale disease', following Milgrom who actually regards it as a medical collective term (Milgrom 1991:774-775), even when he seems to withdraw from that view by explicitly stating that it is not pathology (Milgrom 1991:818). That means that it is not really a disease at all, even when the word, 'disease', will be retained in this study. It is in any event not leprosy as it has become known over a long tradition because of the Septuagint's $\lambda \varepsilon \pi \rho \alpha$ w which actually also means 'scaly condition' (Milgrom 1991:775). In the Priestly source it is always the past participle of the qal-stem (except for the pu'al-stem in Leviticus 14:2). Its equivalent in Akkadian, saharšupp $\hat{u}$, means 'dust-covered', reminding of Job 7:5.

Otherwise many possibilities for the meaning of צִרַעַ have been mooted: psoriasis, seborrhoeic dermatitis, certain mycotic infections, patchy eczema and pityriasis rosea (Hulse 1975:96). Erbele-Küster (2012:212) identifies it as eczema and others have also speculated on its true medical diagnosis. It was probably more of a ritual concern than about physical health or hygiene. That suggests that it was more about the symbolism and meaning of the skin and more specifically of its appearance.

In Leviticus 13 seven categories of skin appearances are dealt

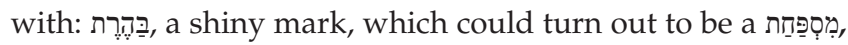

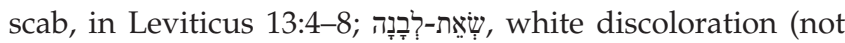
swelling [Milgrom 1991:773]), in Leviticus 13:9-17; שְִׁׁחין, a boil, in Leviticus 13:18-23 and מִכְות-אָש a burn from a fire, in Leviticus 13:24-28, both of which could turn out to be a צָר מָּ scar, literally a burning, in Leviticus 13:23 and 28, respectively;

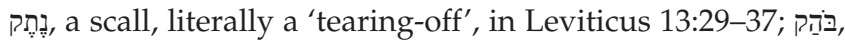
a tetter or a variety of leukoderma, vitiligo, which has 
no flaking, in Leviticus 13:38-39; קרֵ

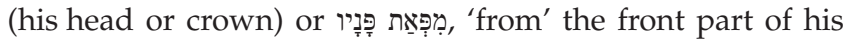
'face', that is, his forehead, respectively in Leviticus 13:40-44

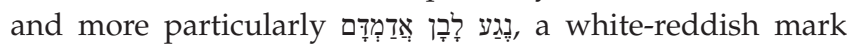

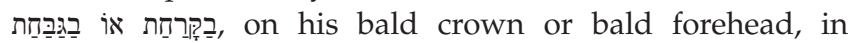
Leviticus 13:42-44.

The five symptoms, some of which are common to several of these seven appearances, are whether the mark is or שָׁפ, that is, deeper or lower than the skin, in Leviticus 13:3, 4, 25, 30, 31, 32 and in Leviticus 13:20, 21, 26 respectively;

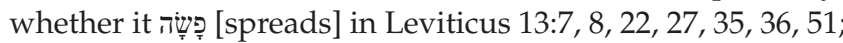

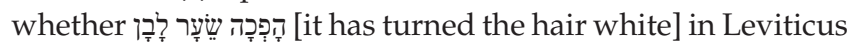

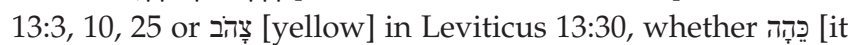
fades] after the quarantine period in Leviticus 13:6, 21, 26, 28,

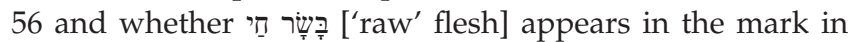
Leviticus 13:10, 14, 15, 16.

Whatever disorders were meant, they would have-according to Anzieu's theories - had an effect on the ego's organisation. The inverse also applies: the skin can also 'say' what is otherwise unspeakable because the symptoms of the body are an unconscious reminder of trauma.

These skin appearances are dealt with in Leviticus 13-14 between the associated conditions of the two transitional processes of childbirth in chapter 12 and İ (one who has an issue, i.e. a genital discharge) in chapter 15 , both to be privately controlled whereas scale diseases were a public and visible matter, dealt with only by professionals, the priests (Milgrom 1991:773), who themselves acted as 'skin' by mediating the inside and the outside of the social body: the priest had to leave the camp in Leviticus 14:3 and so opens himself up for 'infection' in the presence of the suspect. The purification rituals for all three states are also similar though not identical. All three involved the prohibition to touch: those in chapters 12 and 15 to control the sexual drive and that in chapters 13-14 to control the aggressive drive (cf. Anzieu 1995:170). All three were seen as some kind of 'emission' and in Babylonia and perhaps also in Palestine before the reform attributed to the moon god, Sin. All three threaten the integrity of the body by the breach of the body's containing walls and thus making it vulnerable and countering the creation of boundaries by God who, when angry destroys this order and floods the world with emissions (Douglas 1999:189-190). Leviticus 11 deals with yet another transition from outside to inside in the process of eating meat.

In the non-priestly texts of Exodus 4:6; Numbers 12:10 and 2 Kings 5:27 no colour such as לבָנָה [white] in Leviticus 13:3, 4(bis), 10(bis), 13, 16, 17, 19, 20, 21, 24, 25, 26, 38, 39, 43 or

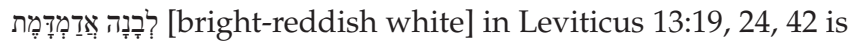

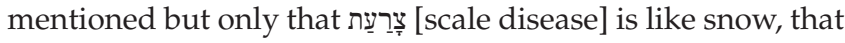
is, exfoliative or desquamative (Hulse 1975:92-93).

Colour plays an important role in all the different forms of the disease in Leviticus 13, however: (Leviticus 13:2, 3, 4, 6, $10,13,16,17,19,20,21,23,24,25,26,28,30,31,37,38,39,42$,
43, 49, 55, 56; Leviticus 14:37) and when it resembles death especially by being white and through the peeling of the skin, it needs to be excluded like a corpse (cf. also Milgrom 1991:819).

The whiteness of either the skin in Leviticus 13:4, 10, 13, 17, $19,38,39,42,43$, of the hair in Leviticus 13:3, 10, 20, 21, 25, 26 and of the flesh in Leviticus 13:16, 24 has different meanings: only in the case of hair is it problematic and might have suggested death. In the case of flesh it is explicitly positive, while in the case of skin it is ambiguous. For that reason the priest would have had to remember exactly the colour and the number of affected hairs after the quarantine period to compare and evaluate its status.

That derivatives of מַּרָ [appearance] occur numerous times (in Leviticus 13:3, 4, 5, 12, 14, 20, 25, 30, 31, 32, 34, 37, 43, 57), a niph'al or an hiph'il form of רָָ [show] in Leviticus 13:7(bis), 17, 49 (here a garment with 'scale disease') and רָאָ [he looks] in 26 places and then always by the priest, indicate that this is more a visual and perhaps aesthetic (which Milgrom [1991:775], however, denies) than a tactile experience. The skin in all its different forms is a presentation to the outside world. In this professional 'manual', which Leviticus 13 is, its image is to be preserved. The fluctuations of life reflected in it seem hard to deal with and condemned as impure.

That the skin is described from a subjective point of view is clear from the narrative about Naaman in 2 Kings 5:9-15, who does not seem to realise his צָרֵֵַ [scale disease] until his Israelite slave girl, an outsider to him, recognises and interprets it as a sign of impurity, that is, identifies it from her own religious perspective. Even as an outsider he is by implication accepted as agent of God and so into and by the Israelite religion and healed from the 'outsider-disease', now transferred to those who act against God's will and so become outsiders themselves in 2 Kings 5:27. Naaman's healing is outside his own country, outside the expected procedures in the Ancient Near East, outside the Israelite palace and even outside the house of Elisha. The question arises, however, why he was allowed into the city. It could be that, what later became postexilic laws, had not yet been implemented in the late 9th century BCE and so strengthens the possibility that the demarcations of Leviticus had to do with processing the exilic trauma of exclusion, separation, loss, fragmentation, violence and a lack of emotional space obviously relived in the postexilic environment.

The same irony can be found with Miriam in Numbers 12:10 who rejects the black outsider Cushite wife of Moses (who also in Exodus 4:6 experiences scale disease), but is then punished by the white outsider-disease.

\section{Anzieu's views on the skin}

Although Anzieu (1995:28) disagreed with Lacan - and thus split French psychoanalysis about the central role of language, and therefore of the text, in relation to the unconscious - his views about the meanings of the skin can be applied to 
a text's characters, or to legal 'personae' as in Leviticus 13-14. Anzieu agrees, in fact, with Freud's implicit conviction that the unconscious is the body.

In Le Moi-peau (originally 1985) he also develops the ideas of the British psychoanalyst, Esther Bick (1968, published in Spillius 1988), about a containing sensual object to bind the parts of the personality before their differentiation from the body (Anzieu 1995:219-220). Bick also understands the skin projected as containing boundary in the ego which keeps and holds the still passive personality parts together and creates the concept of a 'second skin' to compensate for failures in this process. Such a foundational crisis is then also the reason why the schizoid personality structure is rooted in problematic skin experiences before a person becomes moves to the other three erogenous zones (the oral, anal and phallic), which Freud identified.

Anzieu likewise found that those who had suffered skin damage suffered correlative damage to their psychic container or 'envelope' as well. The state of the body as sign of the psychological or spiritual condition is also hinted at in Leviticus 13-14 (Willis 2009:132). Moreover, the skin remembers not only individual but also cultural unconscious trauma.

Every psychic function, organ and agency as well as every character trait derive from a concrete basis in the body. The ego is the projection of the skin in the psyche. Tactile experience therefore determines the capacity for physical and affective closeness and intimacy.

A skin is the bodily basis of the mental image of the experience of the body's surface, the ego which Freud (1949:31) regards as in the first place a body-ego. The skin-ego is an achievement by the infant only when enough goes well to allow the infant to link with the body and its functions, as Donald Winnicott (1965:89) asserts. The skin-ego in turn is rooted in a 'shared skin' where the mother's skin phantasmically includes the infant just as the womb did before and so keeps the mother and the infant fused even after birth. With time the tactile exchanges with the caregiver renders the skin a limiting membrane as the site where the body of the self ends and that of others begins and where body space and a sense of a threedimensional individuality with an inside and an outside develop. This 'flaying' of the common skin as the infant matures is unpleasant and surrender is accompanied by resistance, analogical to Freud's concept of the phantasmical genital castration, perhaps also expressed by circumcision, the removal of the foreskin. The sense of being bound by its own surface allows the infant, however, to transpose its concrete somatic experiences to the abstract psychic realm as a body-ego. Its own surface is therefore (ironically) its most profound experience. In addition, the infant's relationship to the caregiver determines the relationship to its own body and to those of others. The skin-ego includes the introjected hands of the mother who held the infant physically as a solid unit and prevented it from falling and falling apart, in this way supporting the psychic parallel of trust.

\section{Some psychoanalytic functions of the skin in Leviticus 13-14}

Although initially metaphorising the skin-ego as a sac, a screen, a sieve and a mirror, Anzieu eventually identifies eight psychic functions of the skin in health. This theory will now be applied to the information about the conception of the skin in Leviticus 13-14. Some aspects of the way scale diseases are dealt with could have been interpreted from the perspective of other functions as well though.

\section{Maintenance}

The skin's physical support of the skeleton and muscles is like the Winnicottian holding: the interiorisation of the mother's hands allows unity and solidity to the psyche to keep on functioning and being (Anzieu 1995:121-122). A lack of this function results in feeling uncentred and fragmented, fluid and empty. Both Freud (1929:128f., 1986:85, 225) and Jung (1984:116) recognised that buildings, especially houses, often function as symbols for the body or its parts. Apart from the skin as text and texture (vide infra), it also reveals something of the architecture of the body-building. This analogy is clearly seen in Leviticus 14:34-53 where the walls of a house can be affected by the 'same' affliction which can attack a human or animal skin in chapter 13. The formerly afflicted, when he is still מִחוּץ לָאָדָָלו [outside his \{own\} tent] is brought to the entrance of the ideal 'skin' in 14:11.23 where אדֶל מוֹעֵד [the tent of meeting] is held out as promise and hope. Exodus 26:14; 36:19; and 39:34 make clear that the tabernacle was made of two layers of skin, of rams and seals respectively. The tent resembles the skin even to the extent that it is 'dressed' by being veiled in Exodus 39:34.

The question can be asked what would have happened if the mould infected the walls of the Temple. The answer may surface from a halakha reporting that these laws only applied to Jewish homes outside Jerusalem (Liss 2012:117). This would, however, be inconsistent with the tent of meeting which is clearly inside the camp in chapter 14 .

Hartley (1992:191) draws attention to the fact that when the whole skin has become white but remained without open, pussy sores, the person remained clean in the seemingly problematic Leviticus 13:13 which can be explained by the word, כִסָתָה [covers], in Leviticus 13:12.13. In addition, when the whole body is covered by whiteness, there is no further threat of spreading anymore. This supposes that deepening would not happen then either. The white spreading over the whole body has become like another supportive and 'stable' skin or garment, as a skin disease is described in a Mesopotamian prayer to Marduk (Steinert 2012:416n.46). A partial spreading is still like moving and 'living' death in Leviticus 13:7, 8, 22, 27, 35, 36, 51.

Just as the skin, so the law holds the psyche together, especially when the self seems to fall apart in the peeling of the skin which is the case with scale disease. 
Symptoms which were not spreading were at least temporarily acceptable as in Leviticus 13:5, 6, 23, 28, 32, 34, 53,55 . Here the skin fulfilled an aspect of its maintaining function properly by preserving the status quo.

On the other hand, those who are 'leaking', 'liquefying', 'falling through holes' or 'spilling out' need the protection of the law to cover them and others exposed to the threat. This also ties in with the general thinking of Mary Douglas about fixed categories with fixed boundaries from which nothing should 'leak'.

\section{Containment}

Closely tied to the skin's holding function from the outside is the digestion of what has been internalised to imitate the mother's handling and recognition of the infant which it allows on the inside. The reintegration processes within the camp and at the spiritual centre where the tent of meeting is in chapter 14 symbolise this containing function of the skin.

However, open sores, the flaky nature of some forms of skin diseases or fungi on certain materials which would have suggested a threatening loss of the surface as well as reddishness (e.g. on a bald area) which would have reminded of 'raw' flesh and thus a 'hole' in the skin all come down to the point that the destruction of the wholeness of the surface of the body or object renders it unclean as this disintegration would have reminded of non-containment and therefore of death and chaos.

In Leviticus 13:14 it would seem that the scale disease becomes like a new (unacceptable) 'skin' and that it is actually about the loss of (the original) skin exposing raw flesh as the

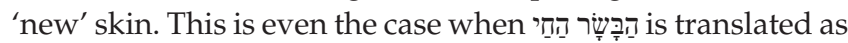
'wildes Fleisch' (granulation [not yet scar] tissue) by Gerstenberger (1993:149). The problem seems to be in the flesh (Willis 2009:124 agrees), not in the skin, but this is only because the unconscious has welded together the two surfaces of the skin which Anzieu (1995:149) identifies and which in a healthy psyche has a 'space' between them so as not to identify the inner arousals with external stimuli.

Just as no one can go without clothes, so too can no one go without skin. The words in Leviticus 13:15 state it

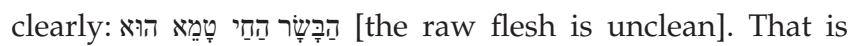
also why scale disease in the form of white discoloration or a

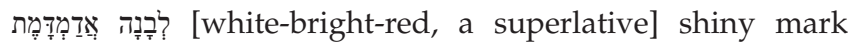
erupting or breaking out (through the skin) in a boil is problematic in Leviticus 13:19-20.

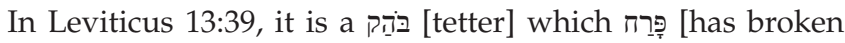
out], although this is regarded as pure, perhaps because it does not flake, which is, however, not mentioned in the

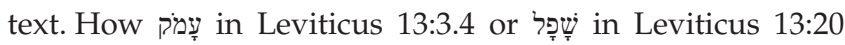
(synonyms: deep or low) the disorder is, shows how 'thin' the skin is. This factor also plays a role in Leviticus 13:30-34 where a נִ [scall] penetrates the skin on the virtually fleshless part of the head and the 'beard', that is, the jaw
(Milgrom 1991:792). It is when the flesh ישיָּיב [contracts, withdraws] in Leviticus 13:16 that new skin can grow back and healing occurs.

Although the שִִׁין [boil] in Leviticus 13:18, 19, 20, 23 covers the afflicted it is a false cover as it makes him 'leak' and so threatens emptying him out. According to Anzieu (1995:122-123) the skin is then perceived as a non-containing sieve through which it loses vital fluids, offering no protection for processing and which threatens to depersonalise the 'patient'.

Baldness, that is the loss of hair, is, however, accepted as natural in Leviticus 13:40-41. The loss of skin, not of (only) hair, registers pathology.

At the same time the שִ שִחין [boil] has associations with heat as in the cognates of Aramaic, Ugaritic and Akkadian (and in English!), which is why Rashi regards it as a sore resulting from flesh growing hot (Milgrom 1991:787). This adds yet another aspect to the idea that the 'attack' on the skin can also

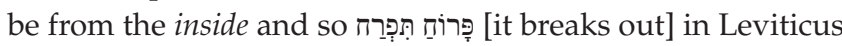
13:12, resonating with Leviticus 13:20 (cf. also Exodus 9:9, 10). This is the opposite of מִכְות-אָש [a fire burn] in Leviticus 13:24 where a new category of skin problem is described which comes from the outside.

The language of Leviticus 13 repeatedly suggests aggression, even military or criminal, through such words or their

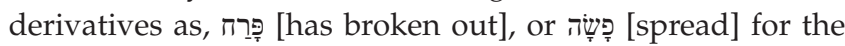
eruptions of someone who does not 'contain' himself. That is

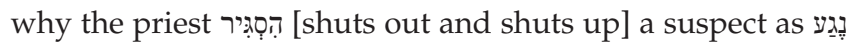
[mark], a depersonalising metonym in Leviticus 13:4, 12, 13, 17, 31 for the afflicted i 9 [in or on whom is] in Leviticus 13:9, $29,44,45,46$ the symptoms which seems to be the priest's sole object of attention and not the afflicted. The marginalised somehow becomes anonymous. Likewise in Leviticus 13:50b

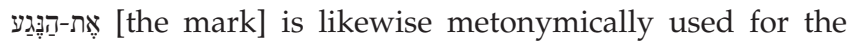
object in which it is.

In Leviticus 13:45 tearing and therefore getting rid of his clothes as protection signifies shame, mourning or both. As a last resort to try and hide his shame and humiliation, the exposed afflicted covers his upper lip or perhaps moustache.

Kaës (1979:53) recognises two other aspects of this function: a receptive passive contained core (or content) by the active peripheral container. This sense of social containment, which sounds here more like control, is strengthened by the passive, ידֶיוּ פְרָרִִים, [they shall be rent], also in Leviticus 13:45 where it is not clear who the subject is: whether the afflicted is exposed as an object by someone else. Earlier, the passive, וְוּוּבָא [then he shall be brought], in Leviticus 13:2, 9 implies that others apart from the priest are also involved as the priest is, in fact, the destination of this action. The initiative of the afflicted is not trusted or accepted and makes him again like a helpless infant to whom physical things are done. This might have meant a constant surveillance by others on the skin of everyone else, again highlighting the inscriptive 
function of the skin. This treating of a passive patient is

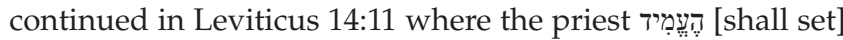
him at the tent of meeting.

\section{Inscription of tactile sensorial traces}

As non-verbal text, screen or mirror the skin communicates, reflects and mediates between the individual and the collective as superego (Anzieu 1995:128-129). As canvas it invites that both inclusion through belonging and exclusion due to insecurities be projected and inscribed. Both parties can consciously or unconsciously identify with these inscriptions as the skin echoes these projections onto it like a resonating membrane.

One could speculate about whether the exclusion of the afflicted was due to possible ritual contagion or due to his appearance which then would have signified something negative, such as death or a hidden (unconscious?) sin, inscribed on his skin.

In addition, the skin speaks about the internal condition of the body and the self. The ancient Israelites were interested in the external manifestation of inner states (Hallpike 1979:390). The colour of the hair betrayed (not necessarily as effect but as sign) the condition of the flesh beneath the skin, as well as the person's spiritual state (Willis 2009:123, 127, 132).

Whether these illnesses, if psychosomatic, betray the psychological state of the individual or even of the community of which they could have been projective identifications, remains open to the 'readers' of the skin.

Pathological body-boundaries replace and represent threatened ego-boundaries as both excluding boundary and contact site (Hirsch 2002:209).

The Egyptians believed drinking the milk of a pig, perhaps an animal sacred to them, produced scale disease. Analogies occur in other cultures across the world where people are believed to descend from certain animals or plants which are then deemed sacred or totemic. Eating these animals or plants would allegedly likewise produce skin diseases. Touching a sacred and therefore dangerous object often requires washing oneself and the clothes worn during the act before entering society, a city or a house, all symbols of the body in the collective sphere (Frazer 1944:473).

That an ancient culture could regress psychologically in the form of somatisation and betray having touched an unclean object having made the forbidden contact should not be excluded as a possibility.

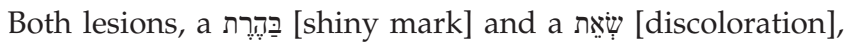

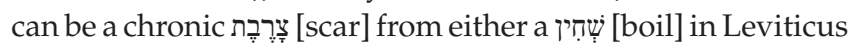
13:23 or a بִכְות [burn] in Leviticus 13:28. They record and reflect remnants from history to the bearer and to the world, a history that is part of identity.
A loss of the capacity to retain traces or the ideal of the collective to which the individual belongs can lead to anxieties of stigmatisation by the superego as a sentence of aesthetic mutilation.

\section{Libidinal recharging}

Stimulation of the body through touch, contact and social care happens at the skin surface to energise and enliven it. To compensate for a lack itching as variability between charge and tension in the skin can be substituted. This would raise the awareness of the afflicted to the crisis that is unfolding on and in his very self due to the lack of this function. When the difference between the internal and external becomes too high an anxiety about explosion from the inside, whence most stimuli arrive at the skin surface, can result (Anzieu 1995:128). These experiences are of course not provided by the text but can add to the possible emotional, internal background to the external events which are the only aspects of the disease described. That the afflicted is already associated with death could reinforce the objective reality of being cut off from life-giving sources.

Touch, proximity and distance play an essential role in Leviticus 13-14. The word, נָגֵע [mark, wound, plague, heavy touch, stroke], or its derivatives occurs 47 times in Leviticus 13 and 14 times in chapter 14, that is, more than two-thirds of the total number of mentions in the Hebrew Bible. To that can be added the inspecting and exposing gaze of the priest, who had to look at the whole and therefore naked body of the suspect, if Leviticus 13:12 is to be taken literally, perhaps experienced as intrusive by the object of examination who is never reported as having spoken even a word. All these forms of aggressive, harsh touching form a contrast to the untouchability of the afflicted precisely as defence against the condition of his skin which threatens aggression in the form of contamination. Yet even the aggressive touch still energises the afflicted as worthy of being touched, despite arousing hyperexcitation.

\section{Excitation filter}

Whereas the recharging function 'invites' stimuli, the most superficial layer of epidermis now protects against excessive stimuli such as aggressive penetration and being flooded (Anzieu 1995:125-126). This layer is clearly disappearing for the afflicted and therefore this function is being undermined. A too thin-skin feeling denuded, is not sufficiently selective and allows too many 'outsiders' to 'enter', typical of the depressive personality (Riemann 2006:86). A lack of this function then leads to the trauma of feeling intruded and possible paranoid anxieties. The skin therefore determines internalisation.

The untouchability of those suffering from a skin disease due to their threatening invasion is shown by their exclusion from society although the priest remains an indirect link and mediator between them and also between the sufferer and God especially in chapter 14 . The main prohibition of both 
obsessional neurosis and the taboo against killing a totem and sexual relationships between members of the same totem group is touching, both literally and in the broadest sense, such as through displacement.

Apart from the eruption from the inside, scale disease is seen as an infiltration from the outside and skin colour change (showing only the potential for the diseases), white or yellow hair, the depth of the affliction (most important), raw flesh and its extent are the four factors determining the seriousness of the intrusion (Milgrom 1991:791)

The exclusion following scale diseases as associations with death and difference and the fact that it is mentioned as a curse on boundary stones as a seal to a contract (Milgrom 1991:820) show that the skin functions psychologically as a boundary and limit keeping the other outside (cf. the prohibition to move a neighbour's landmark for which scale disease would be a punishment in Deuteronomy 27:17 or King Uzziah's transgressing into the Temple in 2 Chronicles 26:16-19).

Lang (2012:314) therefore identifies 'Abgrenzung' (demarcation) as a typical Levitical concept and mentality, and Erbele-Küster (2012:212) notices '[...] die Abwehr unreiner Dinge [ist] ein monotheistischer Abgrenzungsversuch [...]' [the defence against impurities is a monotheistic way to distinguish itself].

The wide-spread occurrence of these 'diseases' across different continents and times as punishments for having transgressed 'boundaries' makes Milgrom (1991:821) suspect that it stems from a common human concern.

These boundaries are extended through clothing and other layers. Psychoanalytically, 'layering' could be interpreted as development: moving away from direct and bare exposure to protective sublimation. The degrees of entering into the social body can be discerned from Leviticus 14:8 where the purified is allowed back into the camp but not directly into his tent or into the tent of meeting which follows only after the 'threshold' ceremonies in Leviticus 14:11.23. This has parallels with the gradual access of priests to the holy in their ordination process in Leviticus 8, marking their 'migration across symbolic boundaries' (Willis 2009:130).

Clothes are like another layer of skin. That is why they are also associated with each other in Leviticus 11:32 and Leviticus 15:17. In fact, in Leviticus 11:32 both are mentioned with a sac and vessels as well, reminding of the maintenance function. Like the skin they also need to be washed to mark a fresh start

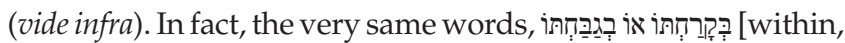
at the backside or without, at the front], are used in connection with materials in Leviticus 13:55 as for the skin in Leviticus 13:42 (in his bald crown or in his bald forehead), as if they are personified. The importance of clothing is suggested by the frequency with which it is mentioned: from Leviticus 13:47

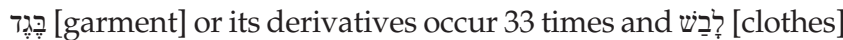
or its derivatives 11 times.
Garments as symbolic extensions of the body, in fact, all fabric covers and containers even including the walls of houses could be afflicted by צֵָָָּ (Leviticus 13:47-59; 14:34-53, 55). This was probably mycotic growths such as fungi, considered by Akkadian texts to be evil (Caplice 1974:40) and therefore to be kept out.

Apart from being infected in both skin and clothing the object of scrutiny, inspection and examination is exposed to nakedness on several levels. The association or even etymological link (cf. Haupt 1919:50) with the word in the Hebrew Bible for nakedness, [ערה], suggests that the skin is also the site of shame, not a mask hiding the real self, but the surface exposing the essence of the self that sometimes needs to be hidden by a 'second' skin to block out aggressors.

\section{Individuation}

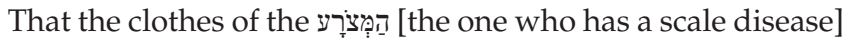
and any other garments, fabric and leather which has a scale disease need to be washed in Leviticus 13:6, 34, 54, 55, 56, 58 like the skin in Leviticus 14:8.9, suggests a new beginning as new identities.

Shaving in Leviticus 13:33, even of a man's beard and eyebrows in Leviticus 14:9, undressing to wash his clothes in Leviticus 13:6, 34, 54, 55, 56, 58(bis) and 14:8-9, 47 and himself in 14:8, 9 before redressing, suggest a shedding of the skin symbolising some kind of rebirth, perhaps tying in with Leviticus 12.

The annual shedding of a snake's skin symbolising initiation and transformation, seems to be simulated by the flaking of skin with scale disease and by the shaving and washing of the purifying הַמְצרָּע [the one who has scale disease]. Even alopecia in Leviticus 13:40-41 suggests a denuding but all these states of nakedness are considered as clean or pure as opposed to nakedness as exposure (vide supra).

The signals on the skin communicate the messages of the excommunicated and mediate the distance and separation between the insiders and the outsiders: just as excretions are leaking from the individual body and these ulcerations make

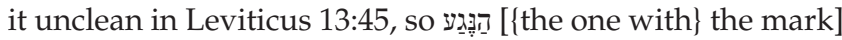
now becomes הַצָּרוּע [the one who has scale disease] and 'leaks' from the collective body. He now also changes his behaviour

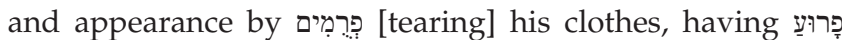
[loosened] (the hair of) his head and יְְִטי (cover[ing], trim[ming]) his moustache (Milgrom 1991:801, 802). Even without physical touch the breath or very presence of a contaminated person made him 'contagious', even when this is not made explicit in Leviticus 13-14 (Milgrom 1991:815816). The victim now lives alone outside the camp according to Leviticus 13:46. The prohibition to touch socially and physically thus creates a boundary defining danger but also reinforces new identity as some kind of individuation (cf. Anzieu 1995:171). This social distance now becomes their new 'skin'. Scale diseases being the worst form of impurity (Milgrom 1991:816), separation even from people who are 
unclean due to other reasons (Milgrom 1991:805) distance the afflicted like a corpse from the living.

When the person is 'healed', he gets yet another new identity, that of הַחמצדרָע [the one with a scale disease], the technical term reserved for the purification ritual and period in Leviticus 14 which is exactly the same as for the corpse-contaminated person and so associates him with death: it was as if he had 'touched' death and so was not to be touched, but now welcomed back to life. This association with death is then displaced by killing (the word occurs 7 times!) animals as sacrifice in Leviticus 14:5, 6, 13(bis), 19, 25, 50. In addition, after purification, shaving in Leviticus 14:8, 9 would have been a temporary message to the world of the former state of the person and the transition to a new person the afflicted has gone through.

Purity seems to mean 'insidership', membership and belonging. The individual can only find personal identity in a group. This notion is apparent from the fact that a [proselyte] was excluded from a אָָָ [person] in the legislation in Leviticus 13:2, 9 (Milgrom 1991:772), incidentally proving that the 'diseases' could not have been physically contagious, but that it somehow undermined the group's visual identity.

\section{Intersensoriality}

This function has to do with being in touch with reality by being receptive to its messages and by integrating them (Anzieu 1995:127).

This function is clearly undermined by the biblical text which never mentions anything of the subjective and sensory experience of the afflicted. No pain, itching or other tactile discomforts are raised. These are therefore clearly irrelevant and unimportant to the author or authors. This confirms once again that the collective skin is not sufficiently containing: it does not reflect and thus confirm the individuality of the afflicted which is limited to belonging thanks to conformity (vide supra).

This function is further undermined when the afflicted is excluded from physical and social touch which would have confirmed his identity in terms of belonging to the collective and would have given him a 'common sense'. The skin as texture is well covered in Leviticus 13-14: a smooth, spotless skin remains the collective ideal to look at and live with, and is therefore also the aesthetic norm.

The prohibition of physical touch is somehow compensated for by the symbolic touching of the gaze (cf. Anzieu 1995:165) and of the voice of the priest (cf. Anzieu 1995:163) who is not distanced from and consequently makes contact with the afflicted. Yet when a suspect is confirmed as afflicted the resulting lack of social and physical touch undermines a sense of the skin as background-screen and thus foundation for the space needed for symbolisation as condensation and integration of stimuli.

\section{Support of sexual excitation}

The interruptions in the skin through eruptions become like additional orifices where additional libidinal energy is invested as base for sexualisation. Outgrowths can produce hypersensitivity as the epidermis is thinner than usual, leading to direct contact with the mucus membrane. Without this external arousal the libidinal recharging of the psyche, that is, preserving its inner tension, is lost. When human touch is lost, it could lead to a more narcissistic than libidinal investment where the person could become so self-centred that he believes himself to be invulnerable and indulges in perverse sexuality where pain is experienced as pleasure. The pleasures derived from some skin sensations stimulate sexuality (Anzieu 1995:127-128), which does not seem to be playing a prominent role during the affliction or even its direct aftermath in Leviticus 13-14. In a regressed form it might only refer to some way of autoeroticism, such as scratching, to animate the afflicted through this difficult transitional if not permanent period of suffering on various levels.

\section{Sociopolitical context}

The views of Anzieu (who also worked on group dynamics) on the individual skin can be transposed to the collective, social skin. For Anzieu (1995:65), every group has a common skin, a containing envelope, which makes it possible for its members to experience the existence of a group self.

Collective belonging within boundaries asserts identity through exclusion of the other. The sense of having been penetrated must have resulted from being intruded upon by the Babylonians, a Fremdkörper, which constituted the violence of the trauma, not only physically and structurally, but also psychically through the anxiety about the threat to the physical. Even later on during the insecurities of the transitional, postexilic phase various defences against anxieties would have been required.

The skin as site of both contact and contagion, by both sacred and profane 'objects', and therefore also of purification (De Vaux 1965:462-644) makes it the medium for sympathetic magic and all its attached anxieties: being in an affected house is like being in an affected skin in Leviticus 14:47. Even being suspected of having been infected and so quarantined for two (but not after one, according to Leviticus 13:23, 28) weeks required the same purification in Leviticus 13:6, 34. Suspected garments, fabrics and leather are likewise 'quarantined' in Leviticus 13:50, 54 and a suspected house also treated as 'quarantined' in Leviticus 14:36-38. The environment is at stake when one individual is affected.

The Hebrew Bible hardly mentions national, but rather reinforces legal, intragroup borders. There often seems to be a centripetal regression to a reduced, almost 'anorexic' though sacred, centre of authenticity, the psychoanalytic id perhaps as the Winnicottian true self, leaving the periphery, the psychoanalytic ego or persona as false self, as profane on 
the edge of the wild desert of demons and chaos which somehow also sometimes supply the (collective) superego to the individual.

If Leviticus, where by far the most awareness of the skin surfaces, reached its final form in the postexilic Persian period (Gerstenberger 1993:10, 12), then it testifies to both a regression to a sensitivity about the skin as both preservation and to individuation, reminding respectively of the compulsive and the schizoid personality types described by Riemann (2006). These personality types can structure a society and the former would emphasise collective purity achieved by separation from other peoples in order to reestablish blurred or abused boundaries due to the trauma of both the penetration and the exile. Rediscovering and reasserting these collective boundaries would have been reflected in individuals. Because of the compulsive personality type's fear of contagion, there is also often a fear of being touched (Anzieu 1995:165).

After the return of some exiled elites from Babylonia and some refugees from neighbouring countries not only was the 'heart' of Jerusalem, the (Second) Temple with its emphasis on blood sacrifice, built in about 515 BCE (Ezr 6:15) and rebuilt in about 458 BCE under Ezra who also enforced the law of Moses (who ironically married a foreigner) and banned mixed marriages of Jews with the 'people of the land' (Ezr 6-10; Neh 8-12), but the destroyed 'skin', the wall, of the reinstated capital - despite its minority - was also repaired under Nehemiah around 444 BCE, and that, despite resistance and conflict from insiders and outsiders (Neh 1-7). Although the competitive struggle was wrought about the centre of this new identity for both those in Palestine as well as those in the diaspora over against the Samaritan Gerizim, its periphery as boundary remained insecure. Yet not the centre but the people from the surrounding area became the source which nourished the 'body' through the 'skin' and its 'orifices'.

Heckl (2016:412) argues for the Hellenistic dating of EzraNehemiah as rewriting of the postexilic events which then reflects later tendencies projected onto earlier material. During the early postexilic time there was even a 'leakage' of priests from Jerusalem to Samaria (Heckl 2016:414). This would change the psychological interpretation from an earlier crisis perspective to a later hardened coresolidification. In fact, it is possible that the threat could have come from the Hellenistic freedom which diluted the boundaries of an identity that still needed firmer exclusion. That would have led to 'second' skin formations, so typical of the schizoid personality type which insists on individuation (Riemann 2006:22ff.).

The fact that the rules became more relaxed with time reinforces our hypothesis that they had been given momentum by the trauma: the Rabbis seem to regard them as less serious than the earlier Qumran Scrolls (Harrington 2004:90).
This would later have allowed openness to others but then perhaps as imperialistic inclusivism where the self is the centre to which they should make their pilgrimages.

\section{Conclusion}

The skin in Leviticus 13-14 remains fragile and penetrable. It is the interface where the world observed, was met, let in or blocked out. These interactions seem to be the case in controlling the skin and to depend on the collective psychic condition of Judah at the time. In the postexilic Jewish community the legislation about the skin is in itself a kind of skin, a border which may not be transgressed and which prevents any trespassing. It keeps the inside together and the outsiders out.

The skin in Leviticus is therefore a palimpsest of meanings in terms of its psychic functions simultaneously covering and discovering a multiplicity of possible suggestions: it is not only part of self-presentation and appearance, but also site of contact and conflict. It is the area of either intimate or cruel touch, and it suggests identity and difference.

\section{Acknowledgements Competing interests}

The author declares that he has no financial or personal relationships which may have inappropriately influenced him in writing this article.

\section{References}

Anzieu, D., 1995, Le moi-peau, Dunod, Paris.

Berlejung, A., 2015, 'Ich bin der Herr, Dein Arzt': Krankheit und Heilung im Alten Orient und im Alten Testament', Welt und Umwelt der Bibel 2, 26-33.

Bick, E., 1988, 'The experience of the skin in early object-relations', in E.B. Spillius (ed.) Melanie Klein today, vol 1, pp. 187-191, Internationaler Psychoanalyse, Munich.

Brown, F., Driver, S.R. \& Briggs, C.A., 1951, A Hebrew and English Lexicon of the Hebrew Bible with an appendix containing the Biblical Aramaic, Clarendon, Oxford.

Caplice, R.I., 1974, The Akkadian Namburbi texts: An introduction, Undena, Los Angeles, CA.

De Vaux, R., 1965, Ancient Israel: Its life and institutions, Darton, Longman \& Todd, London.

Douglas, M., 1999, Leviticus as literature, University Press, Oxford.

Erbele-Küster, D., 2012, 'Die Körperbestimmungen in Leviticus 11-15', in A. Berlejung, J. Dietrich \& J.F. Quack (Hg.), Menschenbilder und Körperkonzepte in alten Israel, in Ägypten und im alten Orient, Orientalische Religionen in der Antike, pp. 209223, Mohr Siebeck, Tübingen.

Frazer, J.G., 1944, The golden bough: A study in magic and religion, Macmillan, New York. Freud, S., [1917] 1929, Introductory lectures on psycho-analysis, George Allen \& Unwin, London.

Freud, S., 1949, The ego and the id, Hogarth, London.

Freud, S., [1900] 1986, The interpretation of dreams, George Allen \& Unwin, London.

Gerstenberger, E.S., 1993, Das 3. Buch Mose: Levitikus, Vandenhoeck \& Ruprecht, Gőttingen.

Hallpike, C.R., 1979, The foundation of primitive thought, Oxford.

Harrington, H.K., 2004, The purity texts, Clark International, London.

Hartley, J.E., 1992, Leviticus, Word Books, Dallas, TX.

Haupt, P., 1919, 'The etymology of 'ôr, skin', Journal of Biblical Literature 38(1-2), 50-51. http://dx.doi.org/10.2307/3260014

Heckl, R., 2016, Neuanfang und Kontinuität in Jerusalem Studien zu den hermeneutischen Strategien im Esra-NehemiaBuch, Mohr-Siebeck, Tübingen.

Hirsch, M., 2002, 'Trauma und Körper: die Verwendung des eigenen Körpers im autobiographischen Werk Georges-Arthur Goldschmidts', in M. Hirsch (ed.), Der eigene Körper als Symbol? Der Körper in der Psychoanalyse von heute, pp. 199222, Psychosozial, Gießen. 
Hulse, E.V., 1975, 'The nature of Biblical leprosy and the use of alternative medical terms in modern translations of the Bible', Palestine Exploratory Quarterly 107, 87-105. http://dx.doi.org/10.1179/peq.1975.107.2.87

Janowski, B., 2009, Der Mensch im alten Israel: neue Forschungen zur alttestamentlichen Anthropologie, Herder, Freiburg.

Jung, C.G., 1984, Dream Analysis: Notes of the Seminar Given in 1928-1930, University Press, Princeton.

Kaës, R., 1979, 'Introduction à l'analyse transitionnelle', in K. René, M. André, K. Raymond, A. Didier, G, Jean, B. José et al. (eds.), Crise, rupture et dépassement: Analyse transitionnelle en psychanalyse individuelle et groupale (Inconscient et culture), pp. 1-81, Dunod, Paris.

Koo, J.Y.M. \& Yeung, J., 2002, 'Body image issues in dermatology', in T.F. Cash \& T Pruzinsky (eds.), Body image: A handbook of theory, research, and clinical practice, pp. 333-341, Guilford, New York.

Lang, B., 2012, 'Die Anthropologie der Leviten', in A. Berlejung, J. Dietrich \& J.F. Quack (Hg.), Menschenbilder und Körperkonzepte in alten Israel, in Ägypten und im alten Orient, Orientalische Religionen in der Antike, pp. 287-319, Mohr Siebeck, Tübingen.

Lisowsky, G., 1958, Konkordanz zum Hebräischen Alten Testament, Württembergische Bibelanstalt, Stuttgart.

Liss, H., 2012, Tanach: Lehrbuch der jüdischen Bibel, Universitätsverlag, Heidelberg.
Miel, D.K., 1990, 'Psychological interpretation', in R.J. Coggins \& J.L. Mouldon, A dictionary of biblical interpretation, pp. 571-572, SCM, London.

Milgrom, J., 1991, Leviticus, [1], 1-16: A new translation with introduction and commentary, Doubleday, New York.

Riemann, F., 2006, Grundformen der Angst: eine tiefenpsychologische Studie, Ernst Reinhardt, Munich.

Schroer, S. \& Staubli, T., 2005, Die Körpersymbolik der Bibel, Gütersloher Verlagshaus, Gütersloh.

Spillius, E.B., 1988, Melanie Klein today, vol 1, Internationaler Psychoanalyse, Munich.

Steinert, U., 2012, Aspekte des Menschseins im alten Mesopotamien: eine Studie zu Person und Identität im 2. und 1. Jt. v. Chr, Brill, Leiden.

Walls, N.H., 2007, 'The origins of the disabled body: Disability in ancient mesopotamia', in H. Avalos, S.J. Melcher \& J. Schipper (eds.), This abled body: Rethinking disabilities in Biblical studies, pp. 13-30, Society of Biblical Literature, Atlanta.

Willis, T.M., 2009, Leviticus, Abingdon, Nashville, TN.

Winnicott, D.W., 1965, Maturational processes and the facilitating environment: Studies in the theory of emotional development, Hogarth, London.

Wolff, H.W., 2002, Anthropologie des Alten Testaments, Christian Kaiser, Gütersloh. 